\title{
A Village-Up View of Sierra Leone's Civil War and Reconstruction
}

\author{
James Bibi Maiah Vincent
}

\begin{abstract}
This article, based on the original report, ${ }^{1}$ offers a 'bottom-up' review of the post-war reconstruction of the Sierra Leone state. The impact of the civil war on human security and governance in the rural areas was devastating, yet rural communities remained intact. The pre-war (traditional) leadership structures continued informally to provide a degree of governance response. Despite the post-war restoration of chieftaincy and its general popularity, elected district councils have been reintroduced. Also, most communities are now using the alternative dispute mechanisms created by donors, who have played a significant role in Security Sector Reform (SSR), democratisation and decentralisation. Although the police are much improved as a consequence, it would be a mistake to say that they are wholly transformed. The various reforms are incomplete and the institutional boundaries of the newly reconstructed multilayered governance system are unclear. Not enough attention has been paid to how governance at the 'periphery' is to be conducted.
\end{abstract}

\begin{abstract}
1 Introduction
Sierra Leone is one of a number of states that underwent a period of civil war and collapse after the end of the Cold War. The international community has devoted considerable resources to the reconstruction of these states but often has found progress very difficult. Typically the focus of attention has been on restoring the structures of the central state - the army, the police, the national bureaucracy - by improving their functioning and their ability to serve the citizenry. However, many of these states collapsed not only because they were not working well but also because they were exploiting their societies. Furthermore, in Africa most states have not only a direct relationship with their citizens as individuals but also a mediated one through rural governance systems that usually pre-date colonialism and may have greater legitimacy than the central state itself (Mamdani 1996; Oliver and Fage 1966). These local governance structures generally have persisted through the collapse and civil war more successfully than the central state has.
\end{abstract}

A set of questions thus arises: Has the international community erred in putting too much emphasis in reconstruction on building out and down from the central state? What role has been and could be played by local governance structures in recreating order and human security? How has the governance capacity of these local institutions been affected by the civil war? Has the sudden abundance of direct services from international providers itself destabilised state-locality-citizen relationships by adding yet another layer to governance?

To answer these questions this article examines the experience of Sierra Leone from the start of its civil war in 1991 through to the present. I have conducted research on these and related questions throughout the country since 1996. For the present study I have supplemented this experience with a qualitative data set based on unstructured interviews in 38 communities in 28 chiefdoms in eight ${ }^{2}$ of the 12 districts in the country during 2010-11. This excludes preliminary meetings with various key stakeholders in the Western Area including key officials in the Ministry of Local Government and Rural Development Services, especially the Decentralisation Secretariat, Ministry of Internal Affairs (especially Senior Police Officers), a number of former ministers, civil society groups, legal practitioners and academics, heads of non-governmental organisations (NGOs), senior politicians from both the ruling party and the opposition, retired civil servants, and some former ex-combatants. 


\section{Background}

There is a considerable set of literature on the causes of the Sierra Leone civil war and its history, which therefore does not need to be rehearsed again here (Abdullah and Mauna 1998; Gberie 1997; Keen 2005; Peters 2011; Richards 1998). I summarise only the key points that are relevant to this analysis.

The fundamental causes of the collapse of Sierra Leone were the civil war in Liberia and its export into Sierra Leone; and in good part the desire to capture the revenues that were available from its alluvial diamond deposits/artisanal diamond fields (as emphasised in Collier and Hoeffler 1998, 2000).

Nonetheless, the movement of the Revolutionary United Front (RUF) into Sierra Leone was facilitated by four key features of the weak Sierra Leonean state: a history of post-independence patronage and corruption; an army that proved easily corrupted and tempted by political power; a corrupt and brutal Sierra Leone Police (SLP); and the disaffection of many young men with their local chiefs, whom they felt were denying them access to the land and resources (and who were easily recruited by the RUF) ${ }^{3}$ (Richards 1998).

The civil war began with the invasion of the country from Liberia by the RUF in March 1991. It was followed by a succession of coups, peace accords, elections and peacekeeping missions by ECOMOG ${ }^{4}$ led by Nigeria, the United Nations (UN), and finally and most successfully by the United Kingdom in 2000, with the war usually seen as ending in 2002. The British were particularly active until 2007 in rebuilding the Sierra Leone military and police force.

\section{Coping with the war}

\subsection{The impact on human security}

The war began in the Eastern Province, gradually spreading to the South and West and reaching the North quite late in the conflict. The RUF attacked not only local officials (especially chiefs) but also brutally killed, maimed and raped civilians who attracted the ire of its irregulars. Human insecurity involves not just stopping attacks on life and limb, however, but also assaults on resources and livelihoods on which communities are dependent. Here too the impact of the war was devastating.

Some communities resisted the rebels, some just gave in, and others voluntarily joined to save the destruction of their property and killing of civilians. The rebels began attacking villages and desecrating sacred bushes, raping women, and killing initiators, Paramount Chiefs (PGs) and lesser chiefs. The communities really protected their chiefs, however, as they refused to identify them to the rebels. There were no national or local police visible (Sierra Leone Police - SLP, or Native Administration Police - NAP). Sometimes, the chiefs were allowed to stay in-post and they agreed because they wanted to protect their people from the wrath of the RUF. The rebels in turn used these chiefs to mobilise resources and get logistics from the community on their behalf. More usually, however, the chiefs would melt into the bush with their people or flee to the towns.

\subsection{The local response}

3.2.1 Civic associations and secret societies

Despite (or perhaps because of) the devastating impact of the war on human security, rural communities remained intact. Food, medicines, education and physical security were all handled as a community and approached in a participatory manner (interactive and community owned). I encountered one entire village that walked with its chief from the Eastern Province to the North, to escape the war in the former only to find itself unfortunately engulfed by its movement to the latter shortly after it got there.

The pre-war (traditional) leadership structures continued informally to provide whatever degree of governance response was possible.

The elders and us, the youths, agreed on protecting ourselves by covering our chiefs. So they stayed with us unrecognised and safe. We lived both in town and in the bush as situations dictated. When it was too unpredictable, they went to the bush; when there was some sanity, they came back and cohabited with them. Our chiefs were really fully in-charge as they had all the powers they had during normal times but did so unnoticed (Youth leader in Nimiyama

Chiefdom, Kono District, 2011).

The survival of chiefdom authority was not universal.

The war destroyed the chieftaincy system and most of the chiefs died. The court system was completely eradicated and replaced by kangaroo courts presided over by [militia] commanders (ibid.). 
However, in the chiefdoms I visited, a third of the chiefs remained with their people (even if in hiding) throughout even the most difficult part of the civil war and most of the rest fled only briefly. Although a large number of chiefs died during the war period, their positions were easily refilled after the war.

In addition to the chiefs, the main social structures pressed into service to provide physical security were the secret societies and the locally recruited Givil Defence Forces (CDF). These helped the chiefs to administer the township as they had moral authority and this was prudently used to manage discipline and create the awareness that the chiefs were still responsible for the maintenance of law and order. The CDF, other secret societies (the Bondo and Poro) and other pre-war associations were key in the reincorporation and improvement in security.

Sierra Leone was blessed with a rich and diverse associational life before the war broke out: the secret societies (male - the Poro, the Wonde, Gbangbani, Hunting and Ojeh; and female Bondo); youth, women's and farmers' associations; football, dance, and social clubs; civil society groups; cooperative societies; and financial clubs (using the Grameen model and the Osusu). ${ }^{6}$ Apart from the secret societies, all other social groups in the communities broke down during the war. Nonetheless, this rich associational life did provide the basis for resistance and order. In Kambia, for instance, the head of the only civil society group became the head of the CDF later. The secret societies were the most popular for mobilisation - even though initiation did not take place regularly during the conflict.

A number of new structures also sprang up during the war and many persisted: the Hindo-Hindo; Mammy Queens (an RUF innovation of village women's chief) $;{ }^{8}$ chairmen in refugee and internally displaced persons (IDP) camps; video, and motorbike riding ${ }^{9}$ clubs; cultural groups; the Sierra Leone Awareness Movement (SLAM); vigilante groups, the CDFs, and Civil Development Units (CDUs). The last three were normally formed in communities as a result of joint requests from the Sierra Leone Army (SLA) and chiefs. They therefore had legitimacy in these communities and commanded some respect. The Tamaboroh mobilised all the secret societies, spiritualists, herbalists, the energies of youths, chiefs, etc. in the chiefdoms and townships. The Donsos were an integral part of the Tamaboroh. Some of the heads of these new structures also acted as chiefs during the war, especially if the incumbent had died or fled. A few of these continued even after the war and were respected because of the way they conducted themselves in very difficult circumstances.

Before the war, the chiefs had been fully in charge of conflict resolution and the running of village activities, including permission to initiate into secret societies. But avoidance of the conflicts that had contributed to the war and the need to involve those who were instrumental to the survival of their communities now dictate a more inclusive approach.

The larger towns and cities developed systems to handle conflicts as committees comprising youths, women, men and elders who were put in place to address palavers, protection of the rights of women and children, and the like. These committees had powers to recommend to the elders that people be fined, punished or sanctioned.

During the war, the CDF and the chiefs ensured that there was some law and order in their villages. Ngiema Dama and Blama Town in the East, and towns and villages in the Liberia boundary area, are typical examples. They provided security for all the citizens in their communities. The local courts, as mentioned earlier, worked on at a lowkey level even during the war. In the North and some parts of Kono District the RUF proxy chiefs (G-5) were in charge of discipline in their communities. They had their committees which had orders from the commander in the area and their decisions were final.

\subsubsection{Civil Defence Forces (CDF)}

Most communities in the South and East created local militias to defend themselves and/or harass the RUF invaders. These forces were weaker in the North and strongest in the South.

The first step came in Kenema Town (in the Eastern Province), where a group related to the male Poro secret society sprang up called the Hindo-Hindo movement. It marked the beginning of a resistance group that was later transformed into a larger Kamajor militia movement, which in turn formed the core of the CDF in the country. 
Similar groups in other parts of the country were Tamaboroh (Koinadugu), Donsos (Kono), Hunting Society (Western Area) and, in the later part of the war, Kapras and Gbethiis (North Temnes). Local self-defence efforts were built around these traditional hunters and extended their training and rituals.

The CDF proper was formed as a result of a request from chiefs in the Eastern and Southern regions and all locals were welcome in the society. It is called a society because it has a secret to keep, a password which helps to identify infiltrators and rogue elements, and a vow to upkeep. Membership was voluntary, not mandatory. Community voluntary contributions were solicited to support them. 'Due to the ineffectiveness of an army without counter insurgency training in protecting civilians and villagers from raids by forest based rebel guerrillas' (Muana 1997), with time the National Provisional Ruling Council (NPRC) military government encouraged all communities to have vigilantes/CDF to help them identify rebels and strangers who could be a source of potential danger to their communities and report to them or their chiefs.

After the democratic elections were won by the Sierra Leone People's Party (SLPP) in 1996, it too encouraged the CDF, and President Kabbah gave them national recognition and made the coordinator of the CDF - Hinga Norman - the Deputy Minister of Defence. The government and the foreign military forces supporting it encouraged all chiefdoms to form the CDF and the PCs to be part of the society for the coordination of logistics. These foreign forces (including ECOMOG, the Executive Outcomes (Sandline) from South Africa, the Gurkhas, and the United Nations Mission in Sierra Leone (UNAMSIL)) helped to train the GDF in modern weaponry and provided them with basic arms and ammunition.

After ECOMOG deposed the second military government and the army defected to the rebels, the civilian

President Kabbah controlled [only] two separate military actors, the ECOMOG [largely Nigerian military force] and CDF. The CDF played a key role in interdicting the RUF supply lines in the South. This unit received very little material support from the government, yet the Kamajor units were regarded amongst the most effective (though never completely trusted) force available to the government (Albrecht and Jackson 2009).

In the Northern region, the scenario was completely different. First, the war arrived there relatively late. Thus the RUF had been able to study the way the CDF operated and had started infiltrating the rank and file of the society... Some [infiltrators] were commanders of RUF battalions and therefore changed their method of attacking their targets. ${ }^{10}$ Second, the SLPP government was less confident of the loyalty of the North, so that the CDF (Gbethiis and Tamaboroh) there was even less well armed than elsewhere, leaving them with only local weapons (cutlasses, machetes, slings, etc.). So the RUF had a fairly easy ride in most of the villages and towns it attacked.

\subsubsection{Social control and CDF abuses}

In the early stages of the war the chiefs controlled those who were recruited into the CDF and therefore were able to ensure that the local CDF behaved responsibly toward them and the communities they were designed to protect. The condition of such control, however, was that the chief had to be a member of the CDF. The Kamajor militia was always part and parcel of the town community. Systems were put in place to ensure that those in arms did not take undue advantage over civilians. As the war progressed, however, initiators in the hunters' and secret societies became indiscriminate in their recruitment (as the initiates paid them fees) and chiefs who were not deeply involved in the actions of the CDF themselves lost authority over them, with the consequence that these CDF carried out abuses, especially when they were recruited to fight in areas away from their homes. But chiefs retained at least some degree of direction over 71 per cent of the CDF in the areas I visited.

\section{Governance in the aftermath}

\subsection{Leadership for the CDF?}

Usually, in the aftermath of a war, those who are prominent in defending their communities are able to claim leadership roles within it. But this has rarely happened in Sierra Leone because of the abuses that occurred.

\footnotetext{
Authority was not shifted to the bad ones; instead [in selecting new chiefs and local councillors] they
} 
considered those from ruling houses and with good character. Whatever contribution they could have made during the war was not a trump card for chieftaincy. The bad guys were in fact stigmatised, ostracised and some have also been sanctioned not to be considered for leadership positions in the community. Sometimes they have also been asked to leave indirectly as they could not feel convenient [comfortable] with the treatment they received from the community members, including their own family. Some have faced mob justice and were also harassed by us for their role in the war (Giema Dama,

Kenema District in the Eastern region).

Elsewhere the chiefs and their subjects said: 'We do not recognise all those who in one way or the other made us suffer in the hands of the RUF or in their own hands'. They were rejected by communities and not given the opportunity to seek any office in the chiefdom or township.

\subsection{Restoration of the chiefs}

Even though grievances against some of the chiefs had led some young people to join the RUF, the institutions of chieftaincy were still quite popular and were easily and universally re-established after the war. In only 19 per cent of our study communities was there any challenge to the return of the traditional chiefs at the end of the war.

Despite the uniformity of the outcome, restoration varied according to the conditions of the local conflict. In many places the RUF had created their own version of a Native Administration (NA) system. Kono District was a special case as they were specifically targeted by the best-trained rebels because of the diamonds and gold found in the district. The rebels therefore overran the district and had a government with proxy chiefs (Mammy Queens and male G-5s).

The chiefs after the war took over with no resistance from any quarter. They had a meeting which was more or less a peace talk with all those who worked as chiefs in their stead and ensured that they worked together for a while before formally retaking power and the $R U F$ proxy chiefs gave up voluntarily to the chiefs (Communities in Bo, Moyamba, Bonthe, Pujehun, in the South and Kenema, Kailahun and Kono in the Eastern region).

In the North, however, very few communities had a peaceful transition, most of the chiefs had to be removed by either force of arms (UNAMSIL,
SLA and the GDF) or the people refusing to recognise their authority.

The rebels in areas where the CDF were active did not occupy the seats of the PC, so transition to the larger political order was smooth. This was the case in all the chiefdom headquarter towns in Moyamba, Pujehun, Bonthe (Rutile),

Kailahun, and Koinadugu.

In some of these places, the GDF had assumed $d e$ facto control in the absence of the chiefs. In other communities the chiefs worked collaboratively with the RUF/CDF for some time (i.e. the PGs used the GDF to enforce laws). Immediately after the war, the central government started reintroducing the local government system by sensitising the people in the communities about re-establishing the councils, and later conducted council elections and trained personnel to staff the various offices. The government brought in some civil servants (on secondment to act as Chief Administrators) and installed the chiefs as members of the newly constituted councils.

Blama was a hot spot during the war because of its strategic location on the main highway between Bo and Kenema (two provincial cities) and a few kilometres from Baojibu and Tongo fields (two diamond fields and therefore a route that leads to Kono - the home of Sierra Leone's diamonds). The chiefs therefore did not have the opportunity to rule without interference during the war. They did not run away into the bush permanently but went in and out as and when there was peace. This notwithstanding, they did not have difficulty linking up with the central government as they managed to maintain their links with the district administration and central government. There was no contest to the powers of the chiefs once the war was declared over.

In cosmopolitan cities like Bo and Kenema, they had no problem with restoration as the civilian administrations were in charge, even during the peak of the war. Bo City was in fact home for all 52 chiefs in the Southern Province. All the chiefs had to do was to return to their homes/ communities and take over from the CDF who had been acting as community leaders whilst their chiefs were away in Bo. In both Bo and Kenema, the government had provincial administrators in place throughout the war and they were quite functional in organising the CDF and other 
developmental programmes in the region. In the East it was slightly different, as some of the chiefs (especially the section and town chiefs) stayed with their people and fought the rebels, as most of these were well-trained hunters and so knew their terrain better than anyone.

Once again, it is surprising that the institution of chieftaincy was so easily restored when its performance had been one of the grievances that led young men to join the RUF. One of the factors in the restoration, obviously, was the abuses conducted by the young in the RUF and many of the CDFs, delegitimising those who might have opposed it.

Another factor was the fact that many chiefs died during the prolonged disruption of the war, so that some of those who were considered abusive were no longer alive. Sensitisation by NGOs and government played a big role in giving the communities hope about replacements of their dead chiefs. Government also facilitated the process of electing the PGs by involving the Independent National Elections Commission (INEC) in conducting all PG elections in the country. In Bo District for instance, there were 15 chiefdoms with PCs and only two survived the war, both very old. ${ }^{11}$

The secret societies ${ }^{12}$ started initiations once more and this encouraged the young men and women to come back as they were key in their lives (they had missed the initiation and dancing for about nine years). The men's secret society especially was useful in organising the young men into groups to help protect the town from the few roaming militias.

Finally, during the war, chiefs made a major change to include youth and women in their governance practices. (The one RUF innovation that has survived the war has been their creation of the role of Mammy Queen in all communities. This survival doubtless also has been aided by the considerable emphasis on women's rights by most of the international assistance and peacekeeping actors.)

\subsection{The implications of local government reforms}

Despite the restoration of the chieftaincy and its general popularity, there are four other signs that the SLPP government was concerned about its lack of broad responsiveness before the war.
First, elected district councils from the early independence period have been reintroduced. Although the Paramount Chiefs are represented on the councils, the elected Ward Councillors and District Chairmen give chiefs competition for leadership. Second, chiefs also have to share their revenues with the councils, which both find a major problem and source of tension. In fact in 94 per cent of the areas I visited there was significant conflict between the chiefs and their district councils. Third, initially the prefectorial District Officers (DOs), who had been the link between the PGs and the central government were made only officers of their councils, which also weakened the influence of the chiefs.

Fourth, the magistrates' courts have been extended and are more accessible. The magistrates may not be incorruptible, but the Native Administration judges/chairmen are believed to have been worse, as all of their income is derived from the fees and fines they impose and as their practices are much less restricted by the law and formal procedures, which Sierra Leoneans now seem to value more than they did in the colonial period. ${ }^{13}$ In the present day, most communities are using alternative dispute mechanisms created by donors to resolve conflicts as they are still afraid of the very high fines that the court chairmen used to levy for common disputes between and within families and households in their communities.

The consequences of the four changes and the preceding tensions are that the post-war chiefs seem to be more moral leaders than authoritative decision-makers and are much more responsive to their communities. But this has left both the NA and the district councils functioning poorly. Chiefs are not a wholly undemocratic institution in Sierra Leone. All local taxpayers participate in their election, and women as well as men are chosen for these offices. Nonetheless, they must be selected from among the descendants of the locality's founding families and they hold office for life. In exiting the war Sierra Leone has seemed to respond to conflicting imperatives - to build on the institutions that have traditional legitimacy, and to provide for more democratic and reliably responsive local governance. This tension does not yet seem to have been finally resolved.

It would appear, however, that the move to democratic decentralisation has stalled, quite 
possibly for partisan reasons, and that the influence of the chiefs is again on the rise. The district councils were abolished in the early independence period by an All People's Congress (APG) government and the APG recaptured the presidency in 2007. Currently eight out of the 19 councils consider themselves as SLPP councils, ${ }^{14}$ whilst the 11 remaining councils are branded APC. Even so, this majority does not give the APC the degree of central control that de-concentration through the DOs and PGs would have provided. Perhaps for this reason, or perhaps for financial ones, further devolution is now stalled. Only 48 of the 84 Statutory Functions and Instruments available for decentralisation have been devolved to the councils to date.

\section{Security sector reform}

Some of the government forces forcibly recruited, school-age boys were conscripted, and women were raped. This left a big gap between the forces and the people they were supposed to protect as it destroyed confidence, trust and hope in the capacity of these forces to protect them from external aggressors.

\subsection{The Sierra Leone Army}

Before the war, communities had respect and a fairly good relationship with most of the Sierra Leone Army (SLA). The SLA was trusted when the war started as people saw them as saviours trying to repel the rebels when they made their first advances to towns and cities. This later changed when the CDF started working with the SLA and discovered that some of the attacks on towns and villages were organised by collaborating soldiers (later called 'sobels'). ${ }^{15}$ This dented the cordial relationship that had existed between the civilians and the SLA.

Matters became even worse when most of the SLA broke with the civilian government and joined the RUF in open rebellion. The consequence was that after the British intervention a wholly new force was recruited. The army was retrained initially by the British Military Assistance Training Team (BMATT) and later by the International Military Assistance Training Team (IMATT). All training facilities were facilitated and led by the UK Department for International Development (DFID). Security Sector Reform (SSR) has since been treated as a governance issue and also multilevelled to ensure the participation of all community members.

SSR played an important role in improving on the internal and external security of communities in particular, and Sierra Leone in general. The project changed the face of security from being looked at as a number of separate entities managed only by uniformed men and women, to one where all players saw themselves as a team.

SSR introduced the Office of National Security (ONS) with a Coordinator that ensured that security was brought to the doorsteps of the people in their various communities. A Central Intelligence and Security Unit (CISU) was created to gather information and process it before forwarding it to the ONS via its Coordinator who then takes it to the National Security Council (NSG), which meets at least once in a month.

Provincial Security Committees (PROSECs) and District Security Committees (DISECs) were set up and Coordinators appointed to staff the offices in the provinces. The DISECs met weekly, and passed on information to the PROSEGs who met biweekly and the PROSEGs then sent these pieces of information to the National Security Coordinator for the information of the NSC. The PCs were key members of these committees as they brought in information from their people at the lowest level of governance.

Approximately $40 \%$ of the population in each district were aware of the existence of the DISECs and PROSEGs and their role in collecting security information. This is [an] impressive statistic given the complete failure of the intelligence structure before and during the war. There is no doubt that not only have significant improvements taken place within the Security System transformation process, but also that they have been noticed and appreciated by local population across a range of districts. Whilst problems still remain, the... greater visibility of the ONS at local level contributed to the general population feeling more secure (Albrecht and Jackson 2009: 194, 197).

The reputation of the SLA has been almost completely restored. They have even started taking part in peace missions throughout the world, especially in Sudan. 


\subsection{The Sierra Leone Police}

The national police also were subject to a major Security Sector Reform initiative, again with British leadership. In this case, the reform involved a restructuring of an existing cadre, not its replacement. Before the war the SLP were hardly present in the rural areas at all, leaving most real rural policing to the NA police.

Before the war, we then had both the SLP and Native Administration Police (aka NA Gbadda) in our midst. The NA Police were more active and present as the PCs were very active and determined to defend their chiefdoms because they had the authority with very little political interference. All conflicts were resolved in the NA and very few serious cases went to the SLP as their presence was not really felt and the people had more trust in their chiefs than the police. We only took conflicts like arson, wounding with aggravation and very serious crimes like murder to the SLP, as they would intimidate the complainant and the victim (Mixed group interview with chiefs and youths in Hangha, Kenema District, 2011).

The SLP was the state actor that we had the least relationship with, as they used to intimidate community members in pre-war SL. During the war, the SLP were targeted in communities as they fell out with people and as a result were targeted by the youths and the rebels alike. They were hardly seen as they lost their credibility before the war and this was the situation till the end of the war (Youths during a Focus Group Discussion in Bo City, Bo District, 2010).

The prolongation of the conflict affected and demoralised all the loyal forces (SLP, SLA, the SL Prisons and SL Fire Forces) as they were the first to be targeted, humiliated and killed in the town square whenever the rebels took over a town. The war ended the rule of law, human rights, and the authority of all the three tiers of governance (central, local and native). As a result, all the local structures were destroyed, some sacred society bushes and shrines completely desecrated, and barracks vandalised, with some completely destroyed.

SLP's reputation, however, has been reinstated with the UK DFID-led Security Sector Reform Project (SSRP) as they have now been retrained and new officers recruited. Some amount of change is now visible, even though the element of corruption is still rife in some junior ranks. Thus the people have now accepted the SLP and are working very amicably with them in their communities. At the end of the war, both the SLA and the SLP by association learnt how to relate well with civilians and at the same time maintain security in communities. It made them realise that they could still make their fortune in the military and police if they could reform their ways. They also saw the way the foreign and international forces treated the community to get information that enabled them to succeed.

As a part of SSR, Local Needs Policing (LNP) was also introduced in all the divisions. As early as 1998 in the

very early stage of the police reform process, the future policing doctrine of the Sierra Leone Police was first defined as Local Needs Policing, which has guided police reform to this day. In its basic form, Local Needs Policing was defined as: 'Policing that meets the expectations and needs of the local community and reflects national standards and objectives' (Albrecht and Jackson 2009).

Another aspect of SSR of the SLP was the Family Support Unit (FSU), which started as a Domestic Violence Unit (DVU) in 1999 after the invasion of Freetown, to handle problems between the ex-combatants and their combat wives,${ }^{16}$ and was soon replicated in all the 26 divisions of the SLP throughout the country. This also helped provide an avenue for women and children to report matters of violence and neglect to the SLP. They were staffed by experienced investigators seconded from the Criminal Investigation Department (CID) of the SLP.

The consequences of SSR are that the SLP are much improved coming out of the war. But unlike the SLA it would be a mistake to say that they have been wholly transformed.

Presently we are cautiously working with the SLP as they have been retrained and given some logistics. There are quite a number that have [played] terrible tricks up till now. They are still chasing money and given unfair judgement in the police stations (Youths in Rokupr Magbema Chiefdom and Kawula-Masungbala Chiefdom, Kambia District, 2011).

The problem is not just one of police practice but also presence. The SL government tried to reconstruct these barracks and build a few new 
ones in strategic locations which were identified as volatile/grey areas in some district

headquarter towns. But some villages up to now still do not have proper police stations, posts or cells. This has slowed down the government's effort to redeploy the various forces and is still continuing to slow the pace at which justice can be accessed by all in the country.

The SLP was still absent or barely present in many of the areas I visited. It was most present in the East and very weak in its presence in over half of the North. Even where the SLP is present in the rural areas its numbers are weak. Given these realities one would think that it is really important for the SLP to be supported in their local work by the NA Police. But there is no national provision for their pay and the chief's source of revenue is now being shared with the district councils.

The word tribal as a prefix to describe the NA Police sounds a little odd but it does perform a basic task and that is, during the days of the colonial master, most of the PCs had to employ and train trustworthy men to provide security for the community. They were led by a Sergeant Major who was a powerful officer/man in the chiefdom. He had powers to order the arrest of anyone thought not to be working in the interest of the chiefdom. NA Police officers collected taxes, fees and licences, and carried out arrests and summons and fines on behalf of the court chairman. This continued until the start of the war in 1991 when their powers started dissipating as the ruling government started maltreating all those PCs they felt were not supporting their government/party. This broke the dynamics in the chiefdom administration and rendered the PCs less effective. The social contract between the chiefdom administration and their subjects was somehow broken and this is affecting the security sector support system in the chiefdoms.

The point here is that SSR of the policing function in Sierra Leone has been incompletely conceived and executed. Not only have insufficient numbers of incompetent and corrupt police been replaced in the SLP to create the kind of thorough reform that was accomplished with the SLA, but the NA rural base for policing was ignored, is starved for support and now rarely functions properly. SSR cannot be accomplished from the capital alone; community institutions have to be supported or changed as well.

\section{Multilayered and networked governance}

A society engaged in conflict and then emerging from it will be subject to networks of relationships by a variety of international actors with its multiple levels of government that are even more critical, fluid and complex than those in the normal state. The question is not whether significant international influences exist in these circumstances but what their implications are for the long-term governance of the society.

\subsection{The security sector}

The first and most obvious place to begin is with those actors directly involved in military operations. The RUF rebellion was ultimately defeated, and their brutality meant that almost none of the insurgent institutional innovations survived it.

The impact of the international forces that assembled over time to defeat the rebellion has been more lasting. At first these were mainly regional forces from Guinea and Nigeria which came on a bilateral military pact; later, ECOWAS decided to send in an intervention force, these two armies were transformed into ECOMOG, with additional troops from Mali, Senegal and Ghana, under Nigerian command. Later the NPRC contracted the South African Mercenaries Executive Outcomes (Sandline) to help protect the diamond fields in Kono District and Tongo in Kenema District. These contributed immensely in training and equipping the CDF. The ECOMOG forces too worked hand-in-hand with civilians.

The transformation in the Nigerian Army contingent after its absorption into the UN force (UNAMSIL) brought about a marked difference in the behaviour of the Nigerian soldiers, as their mandate changed and they began operating under the Geneva Convention. This taught the SLA multiple lessons, including that the military:

a could be respected if it protected and respected the civilians it was supposed to defend;

b must be a disciplined, law-abiding and stable institution; and

c are democratically subordinate to the civilians in power.

After this period, the Nigerian contingent also encouraged dialogue between and within communities, and the training their officers offered to the SLA was the beginning of 
professionalism in the state actors (SLA and SLP especially) and their realisation that they must respect the principles of democratic governance.

The mixture of soldiers from all over the globe allowed people to see the way different military men behave in warfare, not only African forces but also Asian ones from Bangladesh, Pakistan and India as well as the Gurkhas. The British forces also came with permission of UNAMSIL but operated with a long-standing bilateral arrangement and mandate with Sierra Leone.

The peacekeeping missions in Sierra Leone had an impact on the security sector reform process as they were an inspiration to the SLA and SLP, seeing their contemporaries from neighbouring states and other African countries coming in to train them and monitor their performance and behaviour. The police too saw the role of the civilian police in the UN international force. Above all it gave the SLA and SLP some hope that if they behave and measure up to international standards, they too might be drafted into the various peacekeeping missions in the world.

\subsection{Governance}

Democratisation remained a consistent theme of international community pressure on Sierra Leone throughout the civil war and after. This included international pressures for a free and fair presidential election in 2007. Outgoing President Kabbah was under great pressure from his SLPP to overrule the victory of Ernest Koroma of the APC. A united and networked international community (including even China and Iran) persuaded Kabbah to abide by the Electoral Commission's vote count (Leonard et al. 2009).

The donors also ensured that the decentralisation process took off, and then guided the process for a while by having consultants hired to train council officials and monitor the process. In this way multilevelled network governance was reintroduced in the country after 24 years in limbo (under a virtual one-party state).

Dramatic international influence on women's rights also was evident by the conclusion of the war. I have already noted the infusion of gendersensitive policing into the SLP. The need to consult with women and to be more attentive to their rights also was quite evident in my interviews with multiple chiefs throughout the country. Indeed the only RUF institutional innovation that survived the war was the creation of the community office of Mammy Queen for women's issues.

\subsection{Local development}

During periods of conflict local institutions of governance will be more important and there will be more international donors and peacekeepers, who will intervene more widely with greater consequence. Throughout the war the international community's humanitarian relief dealt with the multiple other aspects of wellbeing that contribute to human security, broadly considered. A large number of bilateral and multilateral donors, and a range of UN agencies played a key role. They also networked with communities to support small initiatives through international non-governmental organisations (INGOs) and national NGOs.

The degree of networking with external actors varied from one community to the other. Some village communities especially in the East (Kenema, Kailahun) and South (Bonthe Moriba Town and Rutile) had no networks with external actors but used their local networks in the nearby villages to cope during the difficult periods of the war. Messages were passed and received by utilising bypass roads. Some people had the luck of relating well with the various militias and armies (fighting forces) that took over their villages and towns for a while.

A few communities had refugee and IDP camps near them and these camps were of tremendous help as the NGOs that serviced them also provided them with some assistance/projects as a host community. In parts of the Southern region, for instance, the people from the surrounding small villages abandoned them and came to the largest town/chiefdom headquarter towns, for example Koribondo in the Jaiama Bongor Chiefdom on the main Bo-Liberia highway. In this case, the only external actors they networked with were NGOs (Catholic Relief Services (CRS), Africare and the SL Red Cross) in the Bo axis.

In Bo (Southern Province) networks and linkages were established and maintained with NGOs, as they were and are still, their main source of development aid. Merlin, Care, World Vision, Concern Worldwide, ActionAid, Africare, GTZ (Deutsche Gesellschaft für Technische 
Zusammenarbeit - German Agency for Technical Cooperation) and a host of INGOs were and remain quite visible in the Bo environ. The city council is also networking with donors and financial institutions globally (DFID, World Bank, Islamic Development Bank (IDB) and African Development Bank (ADB)). The INGOs were quite handy during the peak of the war as they were the main network of organisations that the people looked to for their survival.

In Kono (Eastern Province), descendants of the Kamara Chiefdom in the diaspora organised and sent used clothing, money, food and medicines. Individuals and groups volunteered and liaised with the government of Sierra Leone to get logistics for the forces. A new group called MOCKY (Movement of Concerned Kono Youth) sprang up and played a big role in setting up networks and linkages with NGOs, foreign governments and donors at large. The Paramount Chiefs in exile in Europe and the USA also used information received from their villages and chiefdoms to solicit help from donors and wellwishers.

Other areas like Jaiama Sewafe had very few networks with other people or external actors as their villages are not close by - in fact they are all poles apart - so tried to work within their communities, practiced the barter system, and helped each other when in need. The youths were in charge of facilitating such activities in their communities since they could not access help from NGOs and the government.

In the Northern Province, the scenario was different as communities networked with relatives within and around neighbouring villages and chiefdoms, and through linkages in Guinea and Freetown. They also reintroduced and utilised the barter system to break the barrier of currency exchange and to facilitate networking, as there was an acute shortage of physical cash in the region. This was the case in the Koinadugu (Kabala, Yagala, and Bafodia), Bombali and Kambia Districts, especially in those chiefdoms that are near the Guinea border. Coordination was effective within and around nearby societies. Some chiefdoms like Wara Wara Bafodia in Koinadugu District are still not benefiting from interventions by the district council or intervention from NGOs (as has been the case since independence).
As the war wound down, NGOs also played a key role, as they supported food production, provided health services, helped build shelters and rehabilitate community structures, and so on. Supporting NGOs and agencies included Medicines Sans Frontières (MSF), the United Nations High Commissioner for Refugees (UNHCR), Care International, World Vision, the Evangelical Fellowship of Sierra Leone (EFSL), Red Cross, Medical Emergency Relief

International (MERLIN), Caritas and ActionAid, with the help of donors and multi- and bilateral development partners. The government (SLPP in this case) put mechanisms (DDR and NaCSA) ${ }^{17}$ in place to handle issues like schools, health centres, Court Barry reconstruction, ${ }^{18}$ etc.

There were very few national NGOs in the country when the war started. They only started appearing in the mid-1990s when the INGOs needed to intervene in remote communities where they were not allowed to go for security reasons. They started as community-based organisations (CBOs) and later, with the help of the INGOs, some transformed into NGOs. Very few of these NGO/CBOs, however, grew and their capacities were not built by the INGOs.

The extent to which the war created large numbers of unmediated relationships between international actors and villagers has been seen by some analysts as a barrier to state reconstruction: 'Overall, the international community has played a positive role. The big problem is that its very success detracts from the legitimacy of the government' (Kaldor 2006). For a variety of reasons this fear probably is exaggerated. A careful study of this issue in Kenya, where there is a huge density of INGOs and NGOs, found that the state is usually credited for their activities and that government actors most often are involved with what they do (Brass 2010). Similar dynamics can be observed in Sierra Leone.

First, the relationships between international actors and village governance structures in most cases were institutional ones, not too strong and therefore infrequent. Second, the internationals compete against one another, as do the communities themselves, which weakens the quality of the relationships and their influence. From time to time, INGOs had problems between themselves because of this competition for limited resources in the international community. This 
sometimes confuses the recipients and creates an unhealthy environment within the communities they support. Third, local citizens do not know how to access donors. Even though they are well aware of their existence and resources, INGO and NGO programmes and priorities are highly specialised and difficult to understand or access from the bottom. Finally, of course, as the war wound down so did donor involvement. After the war, there was a glut of INGOs in the cities which slowly and surely moved into the rural communities servicing them from the cities. This situation is changing as only a few can now be seen around, each handling a particular area of specialisation.

The consequence of the foregoing four factors is that after 2002 the main external actors most communities interacted with were the development agencies and the local councils that were newly reintroduced in 2004. It thus appears that the formal national and district structures of governance are much more influential for locals in accessing the donor and NGO networks than might have been imagined, given the tremendous financial advantage of the internationals. The communities simply do not have the direct contacts or knowledge to recruit international finance for local priorities.

Thus communities expect to access assistance even from donors or INGOs - through the state or their elected representatives. Nonetheless, as shown above, the role and functioning of the district councils is not secure and the relationship of national Members of Parliament to their communities, now that there are district councillors, also is unclear.

Most MPs do not go to their constituencies as decentralisation has made them uncertain of what they can deliver. In some cases the constituents do not even know them now and are desirous to remove them in the coming elections in November 2012. For some, if they do go to their constituencies, they do so primarily to challenge the councillor on the implementation of development projects within the constituency/ward.

Most of the district councillors do go to their wards but councils lack significant development funds at the moment. Only a few of the councillors grasp the role that they could play in mastering and interceding with the complex structure of international development assistance.
For the three tiers of centre, district and chiefdom/ward to work, the government must be ready to devolve still more functions to the council and also provide or transfer to them more of the funds that the donors send via the Ministries to the councils as this is the main stumbling block in their way.

The resulting quality of the chiefs' relations with their various elected representatives and central government officials is generally mediocre and 82 per cent have contact with no more than two of them. The institutional and financial instability of the councils and the chiefs, rather than the density of international assistance, seems to be the real barrier to responsive local governance.

\section{Conclusions}

Life without the state is always 'nasty, brutish and short' (Hobbes 1939 [1651]). During the war Sierra Leonean men were killed at will and their properties looted. Their wives and children were raped in their presence and they did not have the right to question anything. If they did, the punishment was summary execution.

The social contracts between society and the state, communities and their chiefs, and chiefs with the centre, have been re-established in Sierra Leone - especially in the rural areas. In good part this is due to the powerful negative lesson of what the alternative represents.

Even the youths in the mining fields of Kono prefer state control and peace. But they do feel that their chiefs only hear them during difficult periods like the war. 'Sometimes we prefer statelessness because in this situation we are considered in any meeting as they would need our support' (Youth Chairman in Tombodu, Kamara Chiefdom, Kono District, 2011).

As the foregoing quote suggests, the recovered legitimacy and effectiveness of Sierra Leone's government structures is not just a product of negative learning. It also is due to a far-reaching set of reforms to the key institutions of order in the country - the Native Administration, the SLA, the SLP and the magistrates' courts, and the district councils.

However, there are tensions that will need to be addressed: 
i Security Sector Reform of the SLP is insecure and needs to be reinforced.

ii Chieftaincy seems to be an institution in transition. Is it going to persist only as a source of moral leadership, unifying the communities it serves? Or is it going to undergo changes that would make it more compatible with the universalist and democratic ethos that has grown in Sierra Leone from the war?

iii The tension between the chiefs and the district councils seems a potential source of weakened legitimacy. The re-establishment of District Officers adds further uncertainty. Since there seems to be partisan advantage in the DO development, the instabilities here are potentially great.

iv The various reforms that have come in the wake of the civil war are incomplete and the institutional boundaries of the newly reconstructed multilayered governance system are unclear. The result is that most of the component parts - chiefs, district councils, NA and magistrates' courts, SLP and NA Police, are not functioning as well as they

\section{Notes}

1 An extended report on the research discussed in this article can be found in Vincent (2011).

2 The districts are: Eastern Province: Kenema and Kono; Northern Province: Bombali, Koinadugu and Kambia; Southern Province: Bo, Bonthe and Moyamba. See also map at end of report (Vincent 2011).

3 The denial of land was not necessarily absolute, for it was not always scarce. In Moyamba District, for example, youths had access to up to 3 acres (1.2ha) of land to plant annual and biennial crops (generally for subsistence) but not perennials (which therefore precluded the more lucrative cash crops such as oil palm, cocoa or coffee, which would effectively give a long-term claim on the land). In the Kono and Tongo areas, chiefs were very mindful about allocating long-term use-rights to land that may hold diamonds or gold and preferred to give young people parcels of land that were either barren or had been mined for several years.

4 ECOMOG (the ECOWAS Monitoring Group) is the armed wing of the Economic Community of West African States - the regional organisation comprising 16 states (both anglophone and francophone countries) in West Africa with headquarters in Nigeria. Individual countries contribute troops whenever there is a might. Not enough attention has been paid to how governance at the 'periphery' is to be conducted.

Multilayered, networked governance involving international actors also is a reality but it is much less of a threat to vital states than might have been imagined. States have influence over what donors do, that is much greater than the imbalance in resources would suggest. Citizens are unaware of the true depth of donor influence and give legitimacy to the state for donor presence, and generally can only access donor resources through the state.

It is clear that governance does not disappear when the state collapses. Its structures remain hidden and in retreat, but ready to sprout into existence again. This is true for all parts of government, but it is especially true for the structures of local and rural governance. The consequence is that a post-conflict state has much more need for decentralisation - as well as possibilities for achieving it.

crisis in any of the 16 states. The UN, USA, UK and some other European countries provide the bulk of the operational costs for their deployments and logistics.

5 This is the equivalent of the Poro society in the rest of Mende land. It has a fairly different approach to initiation with a very strict social order/contract and unique names/titles.

6 Osusu is the local name for Rotational Savings and Credit Associations (RoCSAs).

7 The Hindo-Hindo was a password that was used by the Kamajors in the initial stages of the war when they were mobilising. Closely related to the male secret society, Hindo generally means 'man'.

8 'Mammy Queens' are female chiefs appointed during the war. They were not elders during normal times.

9 The riding of motorbikes was another creation of the war. The riders are generally referred to as Okadas, a borrowed word from Nigeria.

10 They would come into a town (or village or city) that they wanted to attack and settle in with the indigenes for a while in order to learn their customs and traditions, their hiding places (Sokoihun), the various routes to enter and escape from the town, which houses had CDF members (the active commanders), note the types and quantities of weapons they had 
in a particular location, and ascertain the direction from which possible reinforcement could come to help repel any attack, etc.

11 Chief Hindowa of Baaja Chiefdom and Chief Gbenga.

12 The secret society refers to the Bondo/Sande, Poro, Gbangbani, and the Wonde.

13 A similar shift in popular sentiment from NA courts toward the magistrates' ones is evident in Ghana (Crook et al. 2010).

14 Bo City, Bo District, Pujehun District, Bonthe District, Moyamba District, Kenema City, Kenema District and Kailahun District.

15 This term refers to soldiers who connived with the RUF and were described as 'soldiers by day and rebels by night'.

\section{References}

Abdullah, I. and Mauna, P. (1998) 'The Revolutionary United Front of Sierra Leone: A Revolt of Lumpen Proletariat', in C. Clapham (ed.) African Guerrillas, Oxford: James Currey

Albrecht, P. and Jackson, P. (2009) Security System Transformation in Sierra Leone, 1997-2007, Birmingham: Global Facilitation Network for Security Sector Reform and International Alert

Brass, J. (2010) Surrogates for Government? NGOs and the State in Kenya, Political Science, Berkeley CA: University of California

Collier, P. and Hoeffler, A. (2000) On the Incidence of Civil War in Africa, Washington DC: World Bank

Collier, P. and Hoeffler, A. (1998) 'On the Economic Causes of Civil War', Oxford Economic Papers - New Series 50.4: 563-73

Crook, R.C.; Asante, K. and Brobbey, V. (2010) Popular Concepts of Justice and Fairness in Ghana: Testing the Legitimacy of New or Hybrid Forms of State Justice, ODI Working Paper 14, London: Overseas Development Institute

Gberie, L. (1997) 'The May 25 Coup d'Etat in Sierra Leone: A Militariat Revolt?', Africa Development 22.3/4

Hobbes, T. (1939 [1651]) 'Leviathan, or The Matter, Forme and Power of a Common Wealth Ecclesiastical and Civil', in E.A. Burtt (ed.), The English Philosophers from Bacon to Mill, New York: The Modern Library: 129-234
16 Women were initially taken as sex slaves after attacks on communities but later considered by senior combatants as wives, therefore referred to as combat wives.

17 The National Commission for Social Action (NaCSA) handled rehabilitation, reconstruction, resettlement and reintegration. Disarmament, Demobilisation and Reintegration (DDR) was set up to handle ex-combatants.

18 Court Barry is a court house in all chiefdoms where the chiefdom court chairman sits his court session and the Paramount Chief also holds chiefdom meetings.

Kaldor, M. (2006) Evaluation of UNDP Assistance to Conflict-Affected Countries, New York: UNDP Evaluation Office

Keen, D. (2005) Conflict and Collusion in Sierra Leone, Oxford: James Currey

Leonard, D.; Pitso, T. and Schmidt, A. (2009) 'The Political Economy of Democratisation in Sierra Leone: Reflections on the Elections of 2007 and 2008', Journal of African Elections 8.1

Mamdani, M. (1996) Citizen and Subject: Contemporary Africa and the Legacy of Late Colonialism, Princeton: Princeton University Press

Muana, P.K. (1997) 'The Kamajoi Militia: Givil War, Internal Displacement and the Politics of Counter-Insurgency', Africa Development 22.3/4: 77-100

Oliver, R. and Fage, J.D. (1966) A Short History of Africa, Baltimore: Penguin Books

Peters, K. (2011) War and the Crisis of Youth in Sierra Leone, Cambridge: Cambridge University Press

Richards, P. (1998) Fighting for the Rain Forest, Oxford: James Currey

Richards, P. and Vincent, J. (2007) 'Sierra Leone: The Marginalization of the RUF', in J.D. Zeeuw (ed.), From Soldiers to Politicians: Transforming Rebel Movement after Civil Wars, Boulder CO: Lynne Rienner Publishers

Vincent, J. (2011) A Village-Up View of Sierra Leone's Civil War and Reconstruction: Multilayered and Networked Governance, IDS Research Report 75, Brighton: IDS 